\title{
Historical Linguistics and Anthropology of Dress in Bulgaria*
}

\author{
Miglena Ivanova \\ Anthropology of Folk Arts and Visual Forms Department \\ Institute of Ethnology and Folklore Studies with Ethnographical Museum - Bulgarian Academy of Sciences \\ IEFSEM - BAS \\ Sofia, Bulgaria
}

\author{
Margaret Dimitrova \\ Department of Cyrillo-Methodian Studies \\ Faculty of Slavic Philologies \\ St. Kliment Ohridski University of Sofia \\ Sofia, Bulgaria
}

\author{
Siemeon Stefanov \\ Bulgarian Etymology Department \\ Institute of Bulgarian Language - Bulgarian Academy of \\ Sciences, IBL - BAS \\ Sofia, Bulgaria
}

\begin{abstract}
The paper presents our work in progress on the scholarly project Local Production, Clothing, and Language Treasure (Contribution to Historical Linguistics and Anthropology of Dress), whose main aim is to study and to edit in an electronic form a little-known archival massif of handwritten documents from 1888 and 1889 preserved at the Scientific Archives of the Bulgarian Academy of Sciences. The documents include 1077 handwritten pages with descriptions of clothing, as well as some photographs made for the illustration of certain data. In its entirety the massif presents in a synchronous cut the territory of Bulgaria in the period shortly after the RussianOttoman war of 1877-1878 and the restoration of the independence of the country. The interpretation of the data from the documents, which are mainly related to local ways of dressing requires voluminous work - paleographic (the documents were written in different handwriting and are sometimes illegible), historical (history of language, history of everyday life, general history, administration, history of language contacts), ethnological, anthropological, etc. At the same time the complex study of the massif will enrich the knowledge about the diversity and wealth of the Bulgarian language in the post-independence decades. Thus, it will become also possible to acquire additional knowledge about certain practices of the young Bulgarian state, for the municipal, county or local administration; for prevailing technologies of production of clothes and the ways of dressing in different villages and cities, as well as for the specific local cultures and everyday life, for many aspects of the social, cultural and economic history of the country in this period. The project also envisages the detailed investigation of the still poorly known reasons for the creation of the massif. In addition, as a result of the summarizing, analyzing and interpreting the data in the massif, the project team will contribute to the reuse of the archival documents in a number of topical research endeavors. It is also important that through the prism of clothing both durable and changeable aspects of various identities from the period will be revealed in their relation to the oral and written language
\end{abstract}

*The project is funded by the Bulgarian National Science Fund (contract No DH 10/12, 2016). proficiency.

Keywords-anthropology of dress; historical anthropology; historical linguistics; history of the Bulgarian language; late 19thcentury

\section{INTRODUCTION}

The paper presents our work in progress on the scholarly project Local Production, Clothing, and Language Treasure (Contribution to Historical Linguistics and Anthropology of Dress) funded by the Bulgarian National Science Fund (contract No DH 10/12, 2016). Being still in the beginning of our work, we will discuss at this particular occasion some of the initial observations, as well as the platform, the objectives, and the expected contributions of the scholarly team.

The main aim of the project is to study and to edit - in an electronic form - a little-known archival massif of handwritten documents from 1888 and 1889 preserved at the Scientific Archives of the Bulgarian Academy of Sciences. The documents include 1077 handwritten pages with descriptions of clothing, as well as some photographs made for the illustration of certain data. In its entirety the massif presents in a synchronous cut the territory of Bulgaria in the period shortly after the Russian-Ottoman war of 1877-1878 and only a decade after the restoration of the independence of the country. The descriptions of the local hand-made clothing of the different ethnic, social, and cultural groups contain plentiful information on the traditional ways of dressing, as well as information on the increasing use of materials and accessories bought in the cities or imported from all over Europe. Unfortunately, the archival massif has never been subjected to systematic analysis albeit it preserves rich data about certain specific features of various types of clothing at the end of nineteenth century as well as about the ways of talking about it and about attitudes towards some typical changes in clothing. Even more, this rare 
source for historical linguistics and anthropology of dress remains unpublished and is almost unknown even to the Bulgarian scholarly community.

\section{STATE-OF-THE-ART}

Initially the information in the handwritten documents (called in the documents reports) was collected on the local spots at the request of the central government of the new independent state and was further sent to the Ministry of Internal Affairs. Later the whole massif together with the photos was transferred to the Ministry of Education. Probably there the well-known Bulgarian specialist in ethnography and folklore studies Ivan D. Shishmanov (1862-1928) was acquainted with the documents, examined them and left notes on some of the margins. Several of his unpublished drafts testify that he had plans to use these documents as a source of valuable lexical and other information. In 1928, shortly before his unexpected death while on a business trip to Oslo (Norway), Professor Shishmanov gave at the Bulgarian Academy of Sciences a scholarly paper on the importance of the study of all the specific designations of traditional clothes. Later the paper was published posthumously as a short article, following his drafts [1]. The publication brings forth several analyses of names of clothes in order to illustrate the broad opportunities of this type of research. Yet, the outlining of the scale that the adequate lexicographical work would have on the whole massif of documents, requires to bear in mind that the names there needing linguistic interpretation are thousands. A similar problem exists with the use of information about other matters of scholarly interest, such as the study of traditional clothing, of their ornaments, manufacturing, differentiation, symbolism, etc. Additional work is also required for the popularization of the documents from the massif as a specific and extremely valuable source because in the course of time they were practically forgotten - their presence is only briefly mentioned in the 1970s by Maria Veleva [2], [3] and in more recent times - in a publication by Miglena Ivanova [4] as well as in a joint publication by Stefan Detchev and Nikolai Vukov [5].

In the times when Ivan D. Shishmanov worked with the massif of documents, the interest in traditional clothing was on a remarkable and long lasting increase. It should be noted, however, that aspects of the different local varieties and names of clothing still remain very important but poorly studied. Thus, their investigation continues even in the last two decades. The massif of documents provides extremely rich data about clothing and the results of the analysis will be of a significant importance for ethnographers, local historians and connoisseurs of local cultural heritage. The idea of the scientific team to endeavor in the complex study of the massif, however, is predominantly related to the valuable information which the documents contain with a view of contributing to a number of topical fields of contemporary research.

The study of the names of the clothes themselves, of their parts and production refers to the history of the Bulgarian language which has been studied since the establishment of the philological science in Bulgaria in the nineteenth century (the already published histories of the Bulgarian literary language of the nineteenth and twentieth centuries are a good source of information for such studies; see for example, the latest of these histories by Diana Ivanova [6]). Yet, the different studies of the vocabulary, as well as of the formation of the administrative register of the Bulgarian language are mostly based on literature texts. Some little-known sources from the nineteenth century still remain unexplored and definitely this is as well the case of the massif of documents about clothing. At the same time, the unexplored sources are important for the study of lexical diversity of the Bulgarian language and about the investigation of the level of literacy of the Bulgarian administration in the period immediately after the restoration of the independence of the country. Parallel to that, in Bulgarian linguistics, despite of the huge lexical data about the richness of the Bulgarian language, there is no glossary of the names of clothes, as well as of their production and use. Although many of these lexemes are present in the dictionary by Naiden Gerov (1895-1904) [7], in the Bulgarian Etymological Dictionary [8] or in a specialized dictionary of obsolete, rare and dialectal words in the Bulgarian literature of the nineteenth and twentieth centuries [9], there is no a specific glossary that provides detailed encyclopedic information on the meaning of the words from this sphere accompanied with photographs of clothes and etymological notes. The regional specifics, the tensions and interactions between colloquial speech and standard language, the correlations of the elements in the semantic groups in the sphere of naming of clothes are also relatively poorly studied.

\section{PROBLEM STATEMENT}

The project presupposes various scholarly approaches towards the diverse information displayed by the massive of documents discussed - such as data about the domestic production of garments, about the fabrics and decorations; about clothing as a marker of social status, gender, age or ethnicity; about tradition and innovation in the way of dressing of different social strata; about the terminology and idioms in Bulgarian language (in multiple dialects), about terminology related to the production of clothing, about cultural borrowings from other languages; about the development and use of photography for documentary purposes in Bulgaria in the late nineteenth century; about the tasks performed by certain categories of civil administration officials for the collection of information in the massif of documents, about the official names of the village and urban settings at the time being; about the names and composition of the administrative units in this period; about the emerging of administrative language register in the late nineteenth century, about the degree of literacy and stylistic proficiency of the clerks, about the standard language etiquette of the administration in the period.

The first step of the work on the project is to produce an electronic edition, both facsimile in color and diplomatic with transcripts of the documents. The edition will be accompanied with commentaries concerning the meaning and origin of the lexemes denoting clothes, fabrics and ornaments, or methods of production, places and language features in terms of style and interference of other languages, such as Turkish, Romanian, Greek, Russian, French, Italian and German. All this information will be structured in a virtual library (database) called Vestiarium. Initial information about the work on the 
virtual library and on the project in general could be seen at the following website: http:// vestiarium-bg.eu.

\section{PROPOSED APPROACH}

The use of electronic processing will enable the implementation of a comprehensive approach that meets the requirements to be:

- Interdisciplinary: as far as it will include various combinations of specific approaches in the field of protection of cultural heritage, ethnology, anthropology, archival studies, paleography, linguistics, areal linguistics, history of the Bulgarian language, ethnolinguistics, comparative linguistics, theory of language contacts, etc., as well as certain methods related to the study of political, economic and cultural history.

- Comparative: the data will be compared with similar data from other sources on the level of synchronous or diachronic studies, on the level of the different regions and ethnic groups, on the level of doing comparisons based on close proximity. Separate comparative analysis on diachronic level and pilot comparisons with similar data for clothing and its names in neighboring countries will be also made.

At this stage of the project we work on the enrichment of the virtual library (database) Vestiarium as well as on its initial analysis at the level of the particular descriptions of clothes with the lexical items denoting them. It seems that the administrators in all the regions of the new independent state received the same instructions how to describe the local clothes. Thus, as a rule, they pay attention to various local specifics and sociocultural characteristics - the differences between particular ethic and religious groups, economic and regional differences, female and male clothes, between the clothes of the married people and bachelors or maids, etc.

For instance, in the report from 26 July 1888 describing the clothes in the region of Razgrad in Northeastern Bulgaria, the clerk notes that the costumes of the bachelors had much more ornaments on the belts, vests, and trousers than those of the married men. He also mentions differences between the local handmade clothes and the imported items, fabrics or accessories, between summer and winter costumes and shoes. At the same time, he states that the Bulgarians and the Turks living in the town of Razgrad had different costumes obtained at different costs. Thus, the average male costume of the Bulgarian costed not more than 50 Levs, whereas the average costume of the Turk costed about 100-150 Levs as far as the first one was predominantly homemade while the second one consisted of clothes bought at the market. The language of description is Bulgarian as it was required in administration, but it includes several Turkisms (often originally borrowed from Persian or Arabic in Ottoman Turkish) and that was typical for the period. Probably the clerk was aware of the local character of some lexical items and therefore he added synonyms in brackets: either words with more general meaning or words that he regarded as more widespread in Bulgarian dialects; e.g. „Вжтрешна бьла риза оть домашно пладно, тжкано отъ иностранна прђжда, съ малка огърница (яка)“ [A white chemise produced of homemade fabric woven from imported yarn, with a little collar] - he used the Bulgarian word of local character ogărnica 'collar', but he clarified it with the Turkish loanword iaka (from Turkish yaka 'collar', see [11]) that was largely used in the nineteenth and twentieth centuries for 'collar' (see [10], [7]). In contrast, he explained a Turkish loanword with a word of Slavic origin in the following phrase: „така и джобоветь на около съ по ньколко ката (ръдове) мъстенъ гайтанъ“ [thus the pockets are decorated with several layers of locally produced woolen braid] - i.e. the clerk first used the Turkish loanword kat 'layer' (from Turkish kat 'layer, floor, costume', see [8]) and then, in brackets, he added the Bulgarian word red 'order, layer'. A similar approach can be seen also in the following phrase: „На главата превързанъ тънъкъ иностраненъ чюмберъ (кжрпа)“ [on the head a thin scarf of a foreign origin is tied] - here the clerk used the local pronunciation of a Turkish loanword, tchiumber 'headscarf' (borrowed from the Turkish çember 'scarf, headscarf' according to [11]) and then in brackets he added the Bulgarian word kărpa - a word with a more general meaning of 'cloth, scarf, headscarf, towel', widespread in Bulgarian. When describing the men's costume of the Bulgarian in Razgrad, the clerk preferred the Turkish loanword elek, largely used even today in Bulgarian for 'a kind of vest' (on its use, see [7], [10]; on its etymon yelek, see [8]), while when describing the costume of the Turk in Razgrad he introduced the loanword dzhamadan (from the Turkish camedan, camadan 'a kind of vest made of woven wool fabric without sleeves, from Persian ğāmädān 'suitcase for clothes', cf. чемадан in Russian; on its origin, see [8]) and then in brackets explains this word with the Turkish loanword elek: Джамаданъ (елекъ) оть сукно обшить на гърдить отпрьдъ съ гайтанъ или сърма“" [Dzhamadan (elek) made of woven fabric decorated on the breast with braid or golden threads]. Similar tendency of explanation can be found in the report from the region of Samokov as far as there several terms denoting various clothes are also explained by means of synonyms.

The people describing the traditional costumes in different regions show different idiolects. Some of them were more literate, followed the orthographic rules that were conservative in this period, some were not and introduced many local dialectal forms. Many of the terms denoting clothes, fabrics, and accessories, were borrowings from Turkish, Greek, or Romanian. Simultaneously, terms of Russian administrative register had already entered the idiolects of some of the clerks: thus they used raport 'report', tchest imam (from Russian tchest' imeiu) 'I have the privilege', upravitel 'governor' that were borrowed when the administration of the independent Bulgarian state was organized following the models of the Russian Empire.

\section{CONCLUSION AND FUTURE WORK}

The work on this project is just at its beginning but we have already promising results and we hope to be able to offer additional evidence about the transformation both of the realia and of the terms in Bulgaria at the turn of the nineteenth century 10 years after the restoration of the independence of the country from the Ottoman Empire and the beginning of the 
establishment of the modern Bulgarian administration with the help of the Russian administration.

The interpretation of the data from the documents, which are mainly related to local ways of dressing requires voluminous work - paleographic (the documents were written in different handwriting and are sometimes illegible), historical (history of language, history of everyday life, general history, administration, history of language contacts), ethnological, anthropological, etc. At the same time the complex study of the massif will enrich the knowledge about the diversity and wealth of the Bulgarian language in the post-independence decades. Thus, it will become also possible to acquire additional knowledge about certain practices of the young Bulgarian state, for the municipal, county or local administration; for prevailing technologies of production of clothes and the ways of dressing in different villages and cities, as well as for the specific local cultures and everyday life, for many aspects of the social, cultural and economic history of the country in this period. The project also envisages the detailed investigation of the still poorly known reasons for the creation of the massif. In addition, as a result of the summarizing, analyzing and interpreting the data in the massif, the project team will contribute to the reuse of the archival documents in a number of topical research endeavors. It is also important that through the prism of clothing both durable and changeable aspects of various identities from the period will be revealed in their relation to the oral and written language proficiency.

\section{REFERENCES}

[1] Ivan Shishmanov, "On the terminology referring to the Bulgarian folk costume," Journal of the Bulgarian Academy of Sciences, Historical and Philological Branch, 44, 1933, pp. 107-120 [Иван Шишманов, “Към терминологията на българските народни носии," Списание на БАН. Историко - филологически клон, кн. 44, 107 - 120].

[2] Maria Veleva, The Bulgarian folk costume with two aprons. Sofia: Publishing House of the Bulgarian Academy of Sciences, 1963 [Мария Велева, Българската двупрестилчена носия. София: Издателство на БАН, 1963].

[3] Maria Veleva, The diversity of Bulgarian folk costumes. Sofia: Nauka i izkustvo, 1970 [Мария Велева, Разнообразието на българските народни носии. София: Наука и изкуство, 1970].

[4] Miglena Ivanova, "Visual Evidence for Varna Gagauz and their shalvars," in The cost, sea, and Europe, Mila Santova, Iva Stanoeva, and Miglena Ivanova, Eds. Sofia: Professor Marin Drinov Academic Press, 2006, pp. 122-136 [Миглена Иванова, "Визуални свидетелства за Варненските гагаузки и за техните шалвари,” в: Брегът - морето Европа, Мила Сантова, Ива Станоева, Миглена Иванова, ред. София: Академично издателство „Проф. М. Дринов”, 2006, 122 136].

[5] Stefan Detchev and Nikolai Vukov, "From the fur cap to sandals: How to create a Bulgarian costume," in Searching for the Bulgarian: Construction of national identity, Stefan Dechev, Ed. Sofia: Research Institute of the Arts, 2010, pp. 159-254 [Стефан Дечев, Николай Вуков. “От калпака до цървулите: как се създава българската национална носия,” във В търсене на българското: конструиране на националната идентичност, Стефан Дечев, ред. София: Институт за изследвания на изкуствата, 2010, 159-254].

[6] Diana Ivanova, History of the modern Bulgarian standard language, Plovdiv: Plovdiv University Press, 2012 [Диана Иванова, История на новобългарския книжовен език. Пловдив: УИ „Паисий Хилендарски“, 2012].

[7] Naiden Gerov, A dictionary of the Bulgarian language, 6 vols, Sofia: Bulgarian writer Press, 1978, a facsimile edition, first edition: 1895-
1904 [Геров, Найден. Речник на българския език, том 1-6. София: Български писател. 1978; оригинално издание: Речник на блъгарский язик с тлъкувание речити на блъгарски и руски. 1895 1904].

[8] Bulgarian etymological dictionary, 8 vols, Vladimir Georgiev et al., Eds, Sofia: Professor Marin Drinov Academic Press, 1971-2017 [Български етимологичен речник, т. 1-8 т. София: Академично издателство, 1971-2017.

[9] A dictionary of rare, obsolete, and dialectal words in the 19th-20thcentury Bulgarian literature, S. Ilchev, A. Ivanova, A. Dimova and M. Pavlova, Eds. Sofa: Publishing House of the Bulgarian Academy of Sciences, 1974 [Речник на редки, остарели и диалектни думи в литературата ни от XIX и XX в. Стефан Илчев, Ана Иванова, Ангелина Димова и Мария Павлова, съставители; Стефан Илчев, ред. София: Издателство на Българската Академия на Науките, 1974].

[10] A dictionary of modern Bulgarian standard language, Stoian Romanski, Ed-in-chief, 3 vols. Sofia: Publishing House of the Bulgarian Academy of Sciences, 1951-1959 [Речник на съвременния български книжовен език, Стоян Романски, главен редактор, т. 1-3. София: Издателство на Българската Академия на Науките, 1951-1959].

[11] Alf Grannes, Kjetil Rå Hauge, Hayriye Süleymanoğlu, A dictionary of Turkisms in Bulgarian. Oslo: Instituttet for sammenlingnende kulturforksskning, 2002. 